\title{
POLITICAL BUSINESS CYCLES IN TURKEY: A MONETARY
}

\section{APPROACH}

\author{
TÜRKIYY'DE POLITIK İŞ ÇEVRIMLERİ: PARASAL BİR YAKLAȘIM
}

\section{Mesut KARAKAŞ ${ }^{1}$}

\begin{abstract}
Politics and economics are two dependent areas that lead to political business cycles. Countries with different development levels encounter political business cycles differently. The existence of political business cycles is mostly researched on the basis of fiscal variables. In this paper, we will be dealing with the existence of political business cycles with respect to monetary variables. Our research utilizes a simple but explanatory time series model. The empirical results show the existence of the opportunistic political business cycles in Turkish economy.
\end{abstract}

Keywords: Political business cycles; Time series analysis; Turkish political economy

Jel Classification: E5; E6; H2; H3

$\ddot{\mathbf{O z}}$

Politika ve ekonomi politik iş çevrimlerine neden olan iki bağımlı alandır. Değişik gelişmişlik düzeyine sahip ülkeler politik iş çevrimleriyle farklı bir şekilde karşı karşıya gelmektedir. Politik iş çevrimlerin varlığı daha çok mali değişkenler ile araştırılmıştır. Bu makalede, politik iş çevrimlerinin varlığı parasal değişkenler göz önüne alınarak ele alınmaktadır. Araştırmamız basit ama açıklayıcı bir zaman serisi modeli kullanmaktadır. Ampirik sonuçlar, Türkiye'de fursatçı politik iş çevrimlerinin varlığını göstermektedir.

Anahtar Kelimeler: Politik iş çevrimleri; Zaman serisi analizi; Türkiye politik ekonomisi

Jel Sinıflaması: E5; E6; H2; H3

\footnotetext{
${ }^{1}$ Arş.Gör.Dr., Gebze Institute of Technology, Department of Economics, mesutkarakas@ @mail.com
} 


\section{INTRODUCTION AND LITERATURE SURVEY}

Political business cycles literature covers mostly developed countries. Mainly, the question of the literature focused on the existence of the opportunistic political business cycles. First works on political business cycles revealed the links with the voting behavior and economy (Kramer, 1971). Tufte (1975) has revealed first strong results and concluded that the growth of real per capita income and inflationary periods affect the elections. In a further work, Tufte (1978) made two main conclusions for US economy. First of all, economy and economic variables are very important on election results in US. Thus, secondly, politicians tend to exploit this situation in order to be re-elected. Because of the behavior of the politicians, the economy follows a cyclic path related to the elections. The economy mostly booms before the elections but it contracts after the election periods. Boom and boast periods are determined exogenously. In a detailed work, Fair (1978) shown that the result of elections are dependent on real per capita GNP, and unemployment. Other macro economic variables do not show considerable effects on political business cycles. Also, he found that US electorates discount past performance of the politicians with a high rate so that only recent performance of the politicians matters.

The theoretical structure of opportunistic political business cycles was developed by Nordhaus (1975). Nordhaus model was based on the Philips curve. Electorates are identical and symbolized by means of a representative voter. Representative voter with a high discount rate wants to see low unemployment with low inflation in the economy. On the other hand, politicians' only aim is to be re-elected. Thus, they tend to use expansionary monetary policies before the elections to decrease unemployment without too much increasing inflation rate. Since inflation rate adjusts after the elections, they can accomplish their aim at the cost of the economy. But, after the election periods, they fight with inflation through contractionary monetary policies. This fight against inflation continues till the next election nears. Again, the politicians try to manipulate the economy by means of monetary expansion. Thus, the economy goes through contractions and expansions based on the political interventions.

There are two main critiques of Nordhaus' opportunistic business cycles model. First of all, monetary policy is not left to the hands of the politicians, but there are independent central banks. Drazen (2000a) and Drazen (2000b) argue that the central banks are independent but they cannot cope with the political pressure. Thus, they accommodate to the political pressures and shape monetary policies in parallel with political demands. So, this 
critique of opportunistic political business cycles is a weak one. The second criticism on the opportunistic political cycles is the voters' irrationality. If the voters live more than one election cycle, they tend to punish the politicians on the second election period, since they will know that a period of low unemployment and inflation before the election will be followed by a period of high inflation and low economic growth. The rationality of the voters is discussed mainly in partisan political cycle framework. The first and fundamental political business cycle models which were included voters' irrationality were established by Rogoff and Sibert (1988) and Rogoff (1990).

Most of the empirical tests take basis from Nordhaus model. Allesina et al. (1997) researched the link between the unemployment, GDP, inflation and political business cycles. Their findings showed that there is no link between unemployment and political business cycles in USA. But they failed to reject the relation between GDP and political business cycles. In a different work, Alessina et al. (1992) studied 18 OECD countries and concluded that there is a strong relationship between inflation and political business cycles in Italy, Germany, France, Denmark, and New Zealand. Also, Haynes and Stone (1989) compared the cyclic behavior of macroeconomic variables with election timing and found a four year cycle on GNP and unemployment which coincides with the timing of elections.

The model established by Nordhaus also allowed researchers to investigate the relationships between other macroeconomic policy instruments and opportunistic political business cycles. Allesina et. al. (1992), Grier (1989), and Williams (1990) studied the relationship between money growth and election timing and they found that the timing of an election has significant effect on money growth.

If fiscal variables are taken into account, past studies found strong links between these variables and election cycles. The cyclic behavior in transfer payments which overlap with election timing was determined by Alessina et. al. (1992) and Allesina and Roubini (1992). But no other fiscal variables were found to be manipulated to win the elections. The study of Keech and Pak (1989) focuses on the cyclic behavior of veterans' benefits and social security payments in USA. They concluded that this mechanism to manipulate the voters is not used any more.

The theoretical framework of Nordhaus model was improved via partisan models. These improvements put aside the opportunistic part of the Nordhaus model. Hibbs (1977) 
presented the first partisan model. The rational expectation content of partisan models was developed by Allesina (1987) and Allesina (1988) and gave rise to rational partisan models.

The studies on political cycles in Turkey are not too many. Even in pure business cycle models, we do not encounter many articles in the literature. Thus, it is worth to explain briefly studies of political business cycles on Turkey.

Tutar and Tansel (2000) researched the relationship between budget deficits and political business cycles in Turkey. They used monthly and quarterly data for budget deficits and other fiscal variables and included the number of fiscal authorities in their equations. They found clear evidence for the existence of political business cycles in Turkey. Moreover, Tutar and Tansel (2000) concluded that the usage of yearly data sets on detection of political business cycles in Turkey give rise to problems, since the effect of election periods vanishes in yearly data. Kuzu (2001) used ARIMA models to detect the existence of political business cycles in Turkey. Many independent variables like central bank credits, currency issued, and M1 supply etc. are used to conclude whether there are opportunistic political business cycles in Turkey or not. Asutay (2004) tried to determine political business cycles in Turkey via utilizing a small sample of data set because of data insufficiency. The conclusion of Asutay (2004) is that Turkish governments use both monetary and fiscal policies to buy votes to be re-elected. Sezgin (2007) used ordinary least square approach and yearly data to determine the relationship between political outcomes and policy instruments in the context of political business cycles. She found that, there are political business cycles in Turkey between 1950 and 2003. Also, she determined that the public expenditure and budget deficit increase in election periods and economic growth is mostly hurt by elections.

The studies on political business cycles tend to ignore a special condition on the Nordhaus model. Nordhaus model assumes that macro economy is driven by elections by means of manipulation. But, good macro conditions can give rise to early elections i.e. good economic conditions may push politicians to shift the election timing to an earlier date. If this is the case, there is no need to manipulate economy through opportunistic political business cycles. On the other hand, based on Nordhaus model, the early elections should stem from the bad economic conditions and some other factors like coalitions. Thus, we should check whether the good economic conditions lead to elections or not. In section 2, we check this fact. Further, we explain the methodology to discuss political business cycles in section 3 and study the existence of political business cycles via monetary variables in section 4 . We 
conclude in section 5 and find an answer via monetary variables to the question that whether there are opportunistic political business cycles in Turkey or not.

\section{THE PROBABILITY OF AN EARLY ELECTION IN TURKEY}

There are two possibilities for incumbents in political systems with variable election terms. First, the incumbents can manipulate the economy via macroeconomic policies to be re-elected. This is the case which is covered by opportunistic political business cycle models. For the second possibility, incumbents can call for an early election, when the economic conditions are well. This second possibility is named as opportunistic election timing. For the existence of opportunistic political business cycles, the requirement of non-existence of opportunistic election timing should be satisfied. That brings the situation when economic conditions are well, the probability of an early election should diminish.

The existence of opportunistic election timing is usually determined via Hausmann Test. This method is utilized by Berument and Heckelman (1998) for UK and Japan. It contains instrumental variables which reflects government approval rate. Because such statistics are not collected in Turkey, this method is not possible to be applied to the Turkish case. On the other hand, a different method can be pursued to deal with the existence of opportunistic election timing. A probit approach that shows "when times are good there is no desire to make early elections in Turkey" and "when times are bad, the possibility of early elections increases" will be sufficient for the non-existence of opportunistic election timing.

The probit model is a binary choice model (Johnston and Dinardo, 1997). The dependent variable $y_{i}$ takes the value of either one or zero depending on a latent variable $y_{i}{ }^{*}$ :

$$
y_{i}^{*}=X_{i} \beta+\varepsilon_{i}
$$

where, $\varepsilon_{i} \square N\left(0, \sigma^{2}\right)$ and $y_{i}=1$ if $y_{i}^{*}>0$ and $y_{i}=0$ otherwise. Then,

$$
\operatorname{Pr}\left(y_{i} \mid x_{i}, \beta\right)=1-\phi\left(-x_{i} \beta\right)=\phi\left(x_{i} \beta\right) \text {. }
$$

where $\phi$ is cumulative standard normal distribution.

The dependent variable is election (ELEC1) and its probability is determined by means of quarterly change in real gdp per capita (CRGDPCAP) and coalition formation (COAN). The coalition formation variable takes three distinct discrete values. The COAN variable takes the value of -1 , if there is only one ruling party in the government; it takes the value of 0 , if there is two ruling parties in government; and if there are more than two ruling 
parties in government, it takes the value of 1. The lags of quarterly change in real gdp per capita are also used in our approach, since both current change in real gdp per capita and past changes in real gdp per capita have effects on early elections. Because of voters' high discount rate, the effect of more current changes in real gdp per capita is expected to have more weight compared to the others.

The quarterly data set which is used covers a period of 1969Q2-2007Q3 for the probit model. Because of the change in the calculation methodology of GDP after the third quarter of the year 2007, the data set cannot be enlarged and limited with periods before 2007. The probit estimation result is given on the Table 1.

Table 1: Probit Model Output for the Period 1969Q2-2007Q3

\begin{tabular}{lll}
\hline Dependent Variable & ELEC1 & \\
\hline Variables & Coefficient & Probability \\
CRGDPCAP & -0.08 & 0.00 \\
CRGDPCAP(-1) & -0.07 & 0.00 \\
CRGDPCAP(-2) & -0.08 & 0.00 \\
CRGDPCAP(-3) & -0.06 & 0.00 \\
COAN & 0.27 & 0.03 \\
\hline
\end{tabular}

The coefficients of all variables are significant at 0.05 level in the output. The signs of real gdp per capita for current, one quarter, two and three quarters before the elections are negative and in parallel with the framework of opportunistic political business cycles. In other words, any decrease in real gdp per capita compared to previous quarter increases the possibility of an early election. Conversely, increases in real gdp per capita decrease the possibility of an early election. Moreover, coalition formation (COAN) variable has significant effect on early elections. If the number of parties that form the government increases, the possibility of an early election increases.

To sum up, lags of change in real gdp per capita affect negatively the probability of an early election. This result points out that early elections are not made when times are good. Conversely, when times are bad, the possibility of an early election increases. As a consequence, these findings show that there is no opportunistic election timing in Turkey. But, there is clear evidence for political business cycles to manipulate the low performing economy and fool the voters through election periods. 


\section{METHODOLOGY}

\section{A. AR(1) Method}

Stationarity of the time series is an important concept in time series analysis. Non stationary series causes spurious regressions most of the time. Thus, we corrected each series that is used in this paper for stationarity. There are mainly two different ways to correct time series for stationarity. One of them is manipulation of the series via algebraic methods like differencing. But, such methods kill the actual meaning of the underlying series. Thus, we did not proceed with this method but followed the second path. The second way to correct time series is to de-trend and correct for seasonality via filtering. In this study, each series were detrended and adjusted for seasonality by means of X12. Additive method is used for the adjustments. The stationarity of the final series is checked utilizing unit root test after adjusting the data series. The augmented dickey fuller test is applied to each filtered data set and all the de-trended and seasonally adjusted series are found to be stationary. The result is actually expected a priori since most macroeconomic series tend to follow a linear trend with seasonal changes throughout the year.

We follow the methodology of Drazen (2000a) after the stationary is provided for each series. Drazen (2000a) establishes the methodology as:

$$
y_{t}=\sum_{i=1}^{s} a_{i} y_{t-i}+b_{0}+\sum_{j} b_{j} x_{j t}+d P D U M_{t}+\varepsilon_{t}
$$

where, $\mathrm{y}$ is outcome variable such as $\mathrm{gdp}, \mathrm{x}_{\mathrm{j}}$ are other economic variables that may also affect $\mathrm{y}$ and PDUM is a political dummy variable which is meant to be representing a political model.

Variables that include other economic factors were excluded in this study, because this paper investigates only the existence of opportunistic political business cycles. On the other hand, lagged values of dependent variables have at most importance in the time series context, because a dependent variable is related heavily to the past values of it.

When ARMA methodology is applied, it is necessary to study correlograms of each series to determine the structure AR, MA, or ARMA equations. For each series, autocorrelation function and partial autocorrelation function were investigated and found that the partial autocorrelation function vanishes after one lag and autocorrelation function diminishes to zero at a considerable pace. Thus, a process of $\operatorname{AR}(1)$ was chosen to be appropriate structure for the methodology of Drazen (2000a) in each series. 
A simple AR(1) process is explained in Johnston and Dinardo (1997) as:

$$
\begin{aligned}
& y_{t}=x_{t}^{\prime} \beta+u_{t} \\
& u_{t}=\rho u_{t-1}+\varepsilon_{t}
\end{aligned}
$$

and after adjustments it becomes;

$$
y_{t}=\rho y_{t-1}+\left(X_{t}^{\prime}-\rho X_{t-1}^{\prime}\right) \beta+\varepsilon_{t}
$$

which establishes the basic framework of this study, since $\left(X_{t}^{\prime}-\rho X_{t-1}^{\prime}\right)=0$ in this paper. Adding election dummy, the procedure that will be followed becomes;

$$
y_{t}=\rho y_{t-1}+\alpha P D U M_{t}+\varepsilon_{t}
$$

\section{B. Data}

Because of the limited availability of monthly data, quarterly data is used through this work. Yearly data was not chosen to be utilized in empirical studies since yearly data tend to blur the effects of elections on monetary variables. The quarterly data sets made us to establish special conclusions on the timing of political manipulation in the economy. The patterns of manipulative activities were constructed in this paper within the 3 months interval to explain the relationship between the macro economy and political business cycles.

The earliest beginning for the data sets is 1964. The ending date of the data sets is 2007. This fact stems from the limitation on the probit model and caused by Turkish Statistical Institute's change on the calculation of the GDP series. The data sets are truncated to the third quarter of the year 2007, because we cannot test opportunistic election timing further in the time interval 2008-2011.

The dependent variables are central bank credits, consumer price index (CPI), inflation rate, currency in circulation, M1 money supply, M2 money supply, and M3 money supply. We aren't able to extend all data sets to the earliest point in the time, because of the usage of different data resources. As a result, we worked on the original data sets without truncating them to a common starting date. The coverage of the data sets is summarized below on the Table 2.

The time coverage of the data sets is summarized below on the Table 2: 
Table 2: Time Coverage of Data Sets

\begin{tabular}{ll}
\hline Variable & Coverage \\
\hline Central Bank Credits & 1986Q1-2003Q1 \\
Consumer Price Index & 1964Q2-2007Q3 \\
Inflation Rate & 1964Q3-2007Q3 \\
Currency in Circuation & 1986Q1-2007Q3 \\
M1 Money Supply & 1986Q1-2007Q3 \\
M2 Money Supply & 1986Q1-2007Q3 \\
M3 Money Supply & 1986Q1-2007Q3 \\
\hline
\end{tabular}

The data set for central bank credits is not extended to 2007, since central bank credits are diminished considerably after 2003. This fact is caused by the independence of central bank and its policy change towards inflation targeting. Also, General Election Dates of Turkey is collected via Belge.net and given on the Table 3:

Table 3: General Election Dates in Turkey

\begin{tabular}{ll|ll}
\hline Election \# & Date & Election \# & Date \\
\hline Election \#1 & 02.05 .54 & Election \#8 & 06.11 .83 \\
Election \#2 & 27.10 .57 & Election \#9 & 29.11 .87 \\
Election \#3 & 15.10 .61 & Election \#10 & 20.10 .91 \\
Election \#4 & 10.10 .65 & Election \#11 & 24.12 .95 \\
Election \#5 & 12.10 .69 & Election \#12 & 18.04 .99 \\
Election \#6 & 14.10 .73 & Election \#13 & 03.11 .02 \\
Election \#7 & 05.06 .77 & Election \#14 & 22.07 .07 \\
\hline
\end{tabular}

We use election dummies based on general election dates and replace PDUM variable in the equation of;

$$
y_{t}=\rho y_{t-1}+\alpha P D U M_{t}+\varepsilon_{t}
$$

Then, the empirical equation that we will be dealing becomes;

$$
y_{t}=\rho y_{t-1}+\alpha E L E C \#_{t}+\varepsilon_{t}
$$

ELEC\# have 15 forms related to the election quarters as ELEC1,.., ELEC15. These forms are defined by:

ELEC1: It takes the value of 1 in the election quarter and 0 otherwise.

ELEC2: It takes the value of 1 one quarter before the election quarter and 0 otherwise.

ELEC3: It takes the value of 1 two quarters $\underline{\text { before }}$ the election quarter and 0 otherwise.

ELEC4: It takes the value of 1 three quarters $\underline{\text { before }}$ the election quarter and 0 otherwise. 
ELEC5: It takes the value of 1 four quarters $\underline{\text { before }}$ the election quarter and 0 otherwise.

ELEC6: It takes the value of 1 one quarter $\underline{\text { after }}$ the election quarter and 0 otherwise.

ELEC7: It takes the value of 1 two quarters $\underline{\text { after }}$ the election quarter and 0 otherwise.

ELEC8: It takes the value of 1 three quarters $\underline{\text { after }}$ the election quarter and 0 otherwise.

ELEC9: It takes the value of 1 throughout the election quarter and one quarter before election quarter; it takes 0 otherwise.

ELEC10: It takes the value of 1 throughout election quarter, one quarter and two quarters $\underline{\text { before }}$ the election quarter; it takes 0 otherwise.

ELEC11: It takes the value of 1 throughout the election quarter, one quarter, two quarters and three quarters $\underline{\text { before }}$ the election quarters; it takes 0 otherwise.

ELEC12: It takes the value of 1 throughout election quarter, one quarter, two quarters, $\underline{\text { three quarters }}$ and four quarters $\underline{\text { before }}$ the election quarters; it takes 0 otherwise.

ELEC13: It takes the value of 1 throughout one quarter and two quarters $\underline{\text { after }}$ the election quarters; it takes 0 otherwise.

ELEC14: It takes the value of 1 throughout one quarter, two quarters and three quarters after the election quarters; it takes 0 otherwise.

ELEC15: It takes the value of 1 throughout one quarter, two quarters, three quarters and four quarters after the election quarters; it takes 0 otherwise.

The detailed usage of election dummies give rise to two advantages. Firstly, the starting period of manipulative activities with respect to the election quarter can be determined. Secondly, the length of manipulation period can be determined i.e. the economy is manipulated for $\mathrm{x}$ quarters before elections. Because of these two reasons, it is useful to use such an extensive set of dummies in the empirical work. On the other hand, using more than one election dummy within the same model jointly causes the error of near singular matrix since different dummy vector sets tend to create dependency within the equations. Because of that, we allowed no more than one dummy in each empirical setup.

\section{EMPIRICAL RESULTS ON MONETARY VARIABLES}

\section{Central Bank Credits:}

Central bank credits to the government are assessed for the time period of 1986Q22003Q1, since these credits becomes insignificant after the period 2003Q1. This fact can be 
related to the independence of central bank. Central Bank throughout time was used a source of government fund by means of seignorage revenues and credits. However, this situation changed after the central bank gained independence and political pressure on the central bank diminished considerably.

Central bank credits seem to increase two quarters before the election quarters, since ELEC2's coefficient is statistically significant and positive in the equation 1 on the Table 4. However, no further results are found such as a contraction of central bank credits after the election quarter. Thus, the result, that central bank credits increase two quarter before the election quarter, is the only derivation that we can make.

Table 4: Empirical Results on Central Bank Credits for the Period 1986Q2-2003Q1

\begin{tabular}{lll}
\hline \multicolumn{2}{l}{ Equation 1 } & \\
\hline \multicolumn{2}{l}{ Dependent Variable } & \multicolumn{2}{l}{ Central Bank Credits } \\
\hline Variables & Coef. & Prob. \\
C & -2550 & 0.41 \\
ELEC2 & 29822 & 0.05 \\
AR $(1)$ & -0.38 & 0.00 \\
Adjusted R^2 & 0.18 & \\
\hline
\end{tabular}

Before the election periods, it is common for politicians to pressure monetary authority and supply more money into the economy at the expense of inflation. Based on the usual methodology above, the coefficient of ELEC5 is found statistically significant with the sign negative for the period of 1986Q1-2007Q3 in the equation 1 on the Table 5. This finding is contrary to our expectations and points out that money in circulation decreases in the fourth quarter prior to elections.

Table 5: Empirical Results on Currency in Circulation for the Period 1986Q1-2007Q3

\begin{tabular}{|c|c|c|}
\hline \multicolumn{3}{|l|}{ Equation 1} \\
\hline \multirow{2}{*}{$\begin{array}{l}\text { Dependent Variable } \\
\text { Variables }\end{array}$} & \multicolumn{2}{|c|}{ Currency in Curcilation } \\
\hline & Coef. & Prob. \\
\hline $\mathrm{C}$ & 1.0022 & 0.00 \\
\hline ELEC5 & -0.0148 & 0.05 \\
\hline $\operatorname{AR}(1)$ & -0.39 & 0.00 \\
\hline Adjusted $R^{\wedge} 2$ & 0.19 & \\
\hline
\end{tabular}


As a second attempt to reveal the relation of currency in circulation and elections, the usual methodology is used on money in circulation/GDP ratio. The rationale behind this is that when economy grows, the money supply should be growing accordingly. However, no significant results are found in the empirical studies.

A third attempt to reveal the relation of currency in circulation and elections is to investigate change in money in circulation. In this empirical setup for the period of 1986Q22007Q3, change in money in circulation is affected significantly via ELEC4 in equation 1 on the Table 6. The sign of coefficient of ELEC4 is positive. This result points out that, in the third quarter before the election quarter, the currency in circulation increased considerably or the speed of contraction in the currency in circulation diminishes considerably.

Table 6: Empirical Results on Change in Currency in Circulation for the Period 1986Q2-2007Q3

Equation 1

Dependent Variable Change in Currency in Circulation

\begin{tabular}{lll}
\hline Variables & Coef. & Prob. \\
C & -0.36 & 0.29 \\
ELEC4 & 4.26 & 0.01 \\
AR(1) & -0.40 & 0.00 \\
Adjusted R^2 & 0.21 & \\
\hline
\end{tabular}

Last setup to reveal the relation of currency in circulation and elections is to investigate change in the currency in circulation/GDP ratio. Fortunately, this model revealed that coefficients of ELEC3, ELEC4, ELEC7, ELEC11, ELEC12, ELEC14, and ELEC15 are statistically significant in the equations $1,2,3,4,5,6$ and 7 on the Table 7 . The coefficients of ELEC3, ELEC4, ELEC11, and ELEC12 are positive. This result points out that the currency in circulation/GDP ratio increases considerably at most for a year before the election period or the speed of the decrease in this ratio becomes so smaller and smaller. The coefficients of ELEC7, ELEC14, and ELEC15 are found to be negative. This finding supports the result that the ratio of currency in circulation/GDP decreases at most four quarters after the election quarter. 
Table 7: Empirical Results on Change in Currency in Circulation/GDP for the Period 1986Q2-2007Q3

\begin{tabular}{|c|c|c|c|c|c|c|c|c|}
\hline \multicolumn{3}{|l|}{ Equation 1} & \multicolumn{3}{|l|}{ Equation 2} & \multicolumn{3}{|l|}{ Equation 3} \\
\hline \multirow{2}{*}{$\begin{array}{l}\text { Dependent } \\
\text { Variable } \\
\text { Variables }\end{array}$} & \multicolumn{2}{|c|}{$\begin{array}{ll}\text { Change in } \\
\text { Currency in } \\
\text { Circulation/GDP }\end{array}$} & \multirow{3}{*}{\begin{tabular}{|l|}
$\begin{array}{l}\text { Dependent } \\
\text { Variable }\end{array}$ \\
Variables \\
C
\end{tabular}} & \multicolumn{2}{|c|}{$\begin{array}{ll}\text { Change in } \\
\text { Currency in } \\
\text { Circulation/GDP }\end{array}$} & \multirow{3}{*}{\begin{tabular}{|l|}
$\begin{array}{l}\text { Dependent } \\
\text { Variable }\end{array}$ \\
Variables \\
C
\end{tabular}} & \multicolumn{2}{|c|}{$\begin{array}{l}\text { Change in } \\
\text { Currency in } \\
\text { Circulation/GDP }\end{array}$} \\
\hline & Coef. & Prob. & & Coef. & Prob. & & Coef. & Prob. \\
\hline $\mathrm{C}$ & -0.17 & 0.68 & & -0.31 & 0.44 & & 0.30 & 0.46 \\
\hline ELEC3 & 3.64 & 0.08 & ELEC4 & 5.63 & 0.00 & ELEC7 & -3.76 & 0.09 \\
\hline $\mathrm{AR}(1)$ & -0.38 & 0.00 & $\operatorname{AR}(1)$ & -0.38 & 0.00 & $\operatorname{AR}(1)$ & -0.36 & 0.00 \\
\hline Adj. $R^{\wedge} 2$ & 0.13 & & Adj. $R^{\wedge} 2$ & 0.18 & & Adj. $R^{\wedge} 2$ & 0.12 & \\
\hline \multicolumn{3}{|l|}{ Equation 4} & \multicolumn{3}{|l|}{ Equation 5} & \multicolumn{3}{|l|}{ Equation 6} \\
\hline $\begin{array}{l}\text { Dependent } \\
\text { Variable }\end{array}$ & \multicolumn{2}{|c|}{$\begin{array}{ll}\text { Change in } & \text { in } \\
\text { Currency in } \\
\text { Circulation/GDP }\end{array}$} & $\begin{array}{l}\text { Dependent } \\
\text { Variable }\end{array}$ & \multicolumn{2}{|c|}{$\begin{array}{ll}\text { Change in } \\
\text { Currency in } \\
\text { Circulation/GDP }\end{array}$} & $\begin{array}{l}\begin{array}{l}\text { Dependent } \\
\text { Variable }\end{array} \\
\end{array}$ & \multicolumn{2}{|c|}{$\begin{array}{l}\text { Change in } \\
\text { Currency in } \\
\text { Circulation/GDP }\end{array}$} \\
\hline Variables & Coef. & Prob. & Variables & Coef. & Prob. & Variables & Coef. & Prob. \\
\hline $\mathrm{C}$ & -0.39 & 0.41 & $\mathrm{C}$ & -0.47 & 0.34 & C & 0.45 & 0.30 \\
\hline ELEC11 & 1.71 & 0.07 & ELEC12 & 1.59 & 0.07 & ELEC14 & -2.09 & 0.06 \\
\hline $\mathrm{AR}(1)$ & -0.36 & 0.00 & $\operatorname{AR}(1)$ & -0.37 & 0.00 & $\operatorname{AR}(1)$ & -0.37 & 0.00 \\
\hline Adj. $R^{\wedge} 2$ & 0.13 & & Adj. $R^{\wedge} 2$ & 0.13 & & Adj $R^{\wedge} 2$ & 0.13 & \\
\hline & & & \multicolumn{3}{|l|}{ Equation 7} & & & \\
\hline & & & $\begin{array}{l}\text { Dependent } \\
\text { Variable }\end{array}$ & \multicolumn{2}{|c|}{$\begin{array}{lr}\text { Change } & \text { in } \\
\text { Currency in } \\
\text { Circulation/GDP } \\
\end{array}$} & & & \\
\hline & & & Variables & Coef. & Prob. & & & \\
\hline & & & $\mathrm{C}$ & 0.54 & 0.23 & & & \\
\hline & & & ELEC15 & -1.95 & 0.05 & & & \\
\hline & & & $\mathrm{AR}(1)$ & -0.37 & 0.00 & & & \\
\hline & & & Adj. $R^{\wedge} 2$ & 0.13 & & & & \\
\hline
\end{tabular}

To sum up, there is strong empirical support on the increase in the currency in circulation before the election quarters. Also, the currency in circulation tends to diminish considerably after the elections. These results favor the existence of an opportunistic political cycle in the currency in circulation.

\section{M1 Money Supply:}

An increase in the M1 money supply before the election period is expected according to the opportunistic political business cycle theory. In our usual setup, M1 or M1/GDP ratio is used as dependent variables but no significant and consistent results are found. Change in M1 money supply reveals also no consistent findings with the theory. On the other hand, change in the ratio of M1 money supply/GDP gives some proper results, if the level of significance is tolerated further. 
When change in the ratio of M1 money supply/GDP is used as dependent variable for the period of 1986Q2-2007Q3, the coefficient of ELEC4 is found to be statistically significant with positive sign in the equation 1 on the Table 8 . This result points out that M1 money supply/GDP ratio increases three quarters prior to the election quarter compared to other periods.

In short, M1 money supply seems to be manipulated, if the effects of GDP are taken into the consideration. M1 money supply tends to increase before the elections more than it is needed, where the need for money supply is mainly controlled via increases or decreases on the GDP. This result supports the expansionary motive of monetary policy before the elections.

Table 8: Empirical Results on Change in M1 Money Supply/GDP for the Period 1986Q22008Q1

\begin{tabular}{llc}
\hline Equation 1 & & \\
\hline Dependent Variable & Change in M1 & Money Supply/GDP \\
\hline Variables & Coef. & Prob. \\
C & 0.10 & 0.74 \\
ELEC4 & 2.37 & 0.10 \\
AR(1) & -0.38 & 0.00 \\
Adjusted R^2 & 0.16 & \\
\hline
\end{tabular}

\section{M2 and M3 Money Supply:}

Even though we expect effects of elections on M2 and M3 money supply, the empirical studies have given no supportive results. The reason can be related to the definition of M2 and M3 money supply. Since M2 and M3 are broader definitions of money supply, the effects of an increase in the monetary instruments may be absorbed by M2 and M3. In other words, M2 and M3 money supplies smooth the changes in the narrower forms of monetary instruments.

\section{CPI and Inflation:}

The effects of elections on CPI and inflation are stated in basic Nordhaus model in the case where politicians take an opportunistic path in policy making. Normally, it is expected that inflation rate and, also, CPI increase considerably after the election periods. However, in the empirical work for Turkey, no such motives on the inflation rates and on CPI index was found. This may be related to chronic and high inflationary periods in Turkey. Since inflation is already high, manipulative activities by governments towards economy cannot push 
inflation rates to higher levels. Most probably, inflation caused by such activities becomes infinitesimal compared to already high inflation rates. This fact shows us that Nordhaus' results on price levels are seen most probably better in countries that have low inflation rates.

\section{CONCLUSION}

The results that we have driven till that point are complicated and blurred. Thus, we will group all empirical results in the Table 9 below so that it is easy to understand and make conclusions.

Table 9: Relations of Monetary Variables with Elections

\begin{tabular}{|c|c|c|c|}
\hline Monetary Variables & $\begin{array}{l}\text { Before the Election } \\
\text { Quarters }\end{array}$ & $\begin{array}{l}\text { In the Election } \\
\text { Quarter }\end{array}$ & $\begin{array}{l}\text { After the Election } \\
\text { Quarters }\end{array}$ \\
\hline Central Bank Credits & High Relation & No Relation & No Relation \\
\hline Currency in Circulation & High Relation & High Relation & High Relation \\
\hline M1 Money Supply & High Relation & No Relation & No Relation \\
\hline M2 Money Supply & No Relation & No Relation & No Relation \\
\hline M3 Money Supply & No Relation & No Relation & No Relation \\
\hline Consumer Price Index & No Relation & No Relation & No Relation \\
\hline Inflation Rate & No Relation & No Relation & No Relation \\
\hline
\end{tabular}

From the Table 9, there are traces of manipulation in the economy via central bank credits, but "expectations on the central bank credits after elections" are not realized i.e. no significant contraction on central bank credits after the election periods is found. But monetary policies are adapted to election cycles, since the currency in circulation and M1 money supply give strong hints. It can be said that the efforts of political manipulation are focused on money printing at the expense of inflation. However, we cannot determine signs of political manipulation on M2 and M3 money supply, most probably because they are broader terms and smooth the effects of manipulation efforts. We haven't found any effects of elections on consumer price index or on inflation. The most probable reason behind this is the existence of chronic and high inflationary periods in Turkey.

Based on the empirical evidence, it is clear that opportunistic political business cycles exist in Turkey. Turkish politicians tend to manipulate economy via monetary instruments before the elections and, afterwards, they try to correct the economy applying tight monetary policies. 


\section{References}

Alesina, A. (1987). Macroeconomic Policy in a Two-party System as a Repeated Game. Quarterly Journal of Economics, 102, 651-678.

Alesina, A. (1988). Credibility and Policy convergence in a Two-party System with Rational Voters. American Economic Review, 78, 796-805.

Alesina, A., Roubini, N., \& Cohen, G. (1992). Political Cycles and the Macroeconomy. Cambridge: MIT Press.

Alesina, A., \& Roubini, N. (1992). Political cycles in OECD Economies. Review of Economic Studies, 59, 663-688.

Asutay, M. (2004). Searching for Opportunistic Political Business Cycles in Turkey. Paper presented in European Public Choice Society.

Berument, H., \& Heckelman, J. C. (1998). Political Business Cycles and Endogenous Elections. Southern Economic Journal, 64(4), 987-1000.

Drazen, A. (2000). Political Economy in Macroeconomics. Princeton, Nj:Princeton University Press.

Drazen, A. (2000). The Political Business Cycle after 25 Years. NBER Macroeconomics Annual, 15, 75-117.

EVDS Central Bank of Turkey. Retrieved from http://evds.tcmb.gov.tr/

Fair, R. (1978). The Effects of Economic Events on Votes for President. Review of Economics and Statistics, 60, 159-172.

Grier, K. (1989). On the Existence of a Political Monetary Cycle. American Journal of Political Science, 33, 376-389.

Haynes, S., \& Stone, J. (1989). Political Models of the Business Cycle Should be Reviewed. Economic Inquiry, 28, 442-465.

Hibbs, D. (1977). Political Parties and Macroeconomic Policy. American Political Science Review, 71, 1467-1487.

Johnston, J., \& Dinardo, J. (1997). Econometric Methods. Irwin: McGraw-Hill.

Keech, W., \& Pak, K. (1989). Electoral Cycles and Budgetary Growth in Veterans' Benefit Programs. American Journal of Political Science, 33, 901-911.

Kramer, G. (1971). Short-term Fluctuations in US Voting Behavior, 1896-1964. American Political Science Review, 65, 131-143.

Kuzu, Y. (2003). Political Business Cycle in the Turkish Economy: 1977-2001. METU Conference in Economics VII September 6-9, 2003, Ankara, Turkey.

Nordhaus, W. (1975). The Political Business Cycle. Review of Economic Studies, 42, 169 190.

Rogoff, K., \& Sibert, A. (1988). Elections and Macroeconomic Policy Cycles. Review of Economic Studies, 55, 1-16.

Rogoff, K. (1990). Equilibrium Political Budget Cycles. American Economic Review, 80, 21-36.

Sezgin, Ş. (2007). Türkiye'de Politik Konjonktürel Dalgalanmalar: 1950-2003 Dönemi. Ankara Üniversitesi SBF Dergisi, 62(2), 136-154. 
Tufte, E. (1975). Determinants of the Outcomes of Midterm Congressional Elections. American Political Science Review, 69, 812-826.

Tufte, E. (1978). Political Control of the Economy. Princeton, Nj:Princeton University Press.

Tutar, İ., \& Tansel, A. (2000). Political Business Cycles, Institutional Structure and Budget Deficits in Turkey. Paper presented in Metu Conference in Economics.

Türkiye Seçimleri. Retrieved from http://www.belgenet.net/

Williams, J. (1990). The political Manipulation of Macroeconomic Policy. American Political Science Review, 84, 767-795. 